\title{
Playing Mathematics in Early Childhood Based on Semiotics
}

\author{
Christine Wulandari Suryaningrum ${ }^{1}{ }^{\bowtie}$, Misyana $^{2}$, Tri Endang Jatmikowati ${ }^{3}$ \\ Pendidikan matematika, Universitas Muhammadiyah Jember(1) \\ Pendidikan Guru Pendidikan Anak Usia Dini, Universitas Muhammadiyah Jember(2) \\ Pendidikan Guru Pendidikan Anak Usia Dini, Universitas Muhammadiyah Jember(3) \\ DOI: $10.31004 /$ obsesi.v6i2.1341
}

\begin{abstract}
Playing mathematics in early childhood based on semiotics gives children the opportunity to identify objects, look for signs and interpret signs so that they can solve problems in games. This study aims to describe semiotic based early childhood mathematics play activities. The research was conducted at the PAUD Lab School, Muhammadiyah University of Jember. The research subjects were 5 children from group $B$. The results showed that the activities of playing mathematics in early childhood based on semiotics were (1) collecting information related to semiotic-based math games, (2) looking for objects that matched the game and counting the number of objects found, (3) looking for relevant signs and signs. that are relevant to the number of objects found, (4) associated with signs of knowledge that have been previously possessed and look for all signs according to the objects found, (5) the child retells the play that has been done.
\end{abstract}

Keywords: early childhood; playing mathematics; semiotic.

\begin{abstract}
Abstrak
Bermain matematika pada anak usia dini berbasis semiotic memberi kesempatan kepada anak untuk mengidenifikasi objek, mencari tanda serta menginterpretasi tanda hingga dapat memecahkan masalah permainan. Penelitian ini bertujuan untuk mendeskripsikan kegiatan bermain matematika anak usia dini berbasis semiotik. Penelitian dilakukan di Lab School PAUD, Universitas Muhammadiyah Jember. Subjek penelitian berjumlah 5 anak dari kelompok B. Hasil penelitian menunjukkan bahwa kegiatan bermain matematika pada anak usia dini berbasis semiotik adalah (1) mengumpulkan infomasi terkait peraturan permainan matematika berbasis semiotic, (2) mencari benda yang sesuai dengan permainan dan menghitung jumlah benda yang ditemukan, (3) mencari tanda yang relevan dan memilih tanda yang relevan dengan jumlah benda yang ditemukan, (4) mengaitkan tanda dengan pengetahuan yang telah dimiliki sebelumnya dan mencari semua tanda sesuai dengan benda yang ditemukan, (5) anak menceritakan kembali kegiatan bermain yang telah dilakukan.
\end{abstract}

Kata Kunci: bermain matematika; anak usia dini; semiotik.

Copyright (c) 2021 Christine Wulandari Suryaningrum, Misyana

$\triangle$ Corresponding author :

Email Address : christine.wulandari@unmuhjember.ac.id (Jember, Jawa Timur, Indonesia)

Received 4 May 2021, Accepted 6 Juni 2021, Published 17 Juni 2021 


\section{INTRODUCTION}

Playing for children not only gives children freedom to have faith, but by playing without realizing it, children can learn to understand rules, solve problems, be patient to wait their turn to play, know the opportunities in the game, namely winning and losing. According to (Guirguis, 2018) playing provides important functions such as general learning strategies and skills as well as, creative thinking, positive self-esteem and different thinking. The term play is difficult to define and articulate because play is abstract and has multiple meanings for different groups and individuals. Play as a voluntary movement across borders, opening with total absorption into a very flexible plane, releasing tension in a playful way, exposing the player to the unexpected. Through play, children entering kindergarten develop problem solving skills, adaptive abilities, and social skills (Rohmah, 2016). The power of play as a learning tool in childhood as well as a force for the physical, social and emotional development of early childhood. In accordance with the principle of learning that to stimulate all the potential of children, namely learning through play (Sari et al., 2019)

According to (Pratiwi, 2017) playing for early childhood has a very important meaning for children's growth. Hal ini sesui dengan pendapat There are sixteen important meanings of play for children's development, namely: 1) Playing can help children's growth and development, 2) Playing is an activity carried out by children without any pressure or coercion from others, 3) Playing gives children freedom to choose and play games, 4) Playing gives children the freedom to fantasize according to their imagination, 5) Playing gives children the opportunity to have an adventure. 6) Through play, children can develop language skills, 7) Play has an effect on children's social emotional abilities, 8) Play gives children the opportunity to develop their physical motor skills, 9) Play can generate interest and focus children's attention, 10) Play can stimulate children to do investigation, 11) Play can provide opportunities for children to role play into adults, 12) Play is a dynamic way for children to learn, 13) Play can make children clear to consider 14) Play can be planned academically, 15) Play is a the strength of children to be able to live socially, 16) Play is an activity that is essential for early childhood education

In mathematics, the study of signs is semiotic. In mathematics learning, children learn for the first time exclusively with signs. Mathematical activities are carried out by interpreting and transforming signs. Learning mathematics does not only involve taking the meaning of the conversion of mathematical signs, but also depending on various possible interpretations. Semiotics in mathematics is defined as the use of symbols that are very helpful in understanding thought processes, symbolizing, and communicating (Ostler, 2011). Early childhood is in the concrete operational stage, children will easily conceptualize mathematics by using signs. Early mathematical concepts for early childhood include aspects of numbers and geometry (Laily et al., 2019).

Learning mathematics in early childhood is mostly done with games. Counting games are part of mathematics that are needed to develop mathematical concept recognition skills that are useful for everyday life, especially recognizing number symbols which are the basis for developing cognitive abilities (Fauziddin, 2015). Playing mathematics can use objects around the child. The use of existing media in a child's environment can introduce children to play mathematics in early childhood by using signs in the environment as a unique learning medium. Learning mathematics in early childhood can manipulate objects. Through play activities, children learn more through playing and exploring objects and experiences (Pradana, 2016) . Therefore, learning must be practical. Informal mathematical activities should be undertaken for a solid foundation of mathematical concepts and skills for further education. In pre-mathematics ata mathematics for early childhood includes algebra, numbers, geometry, measurement, and commercial arithmetic (Nakawa, 2020).

Play will be meaningful for early childhood through games (Munawaroh, 2017) Playing with signs gives children the opportunity to interpret the signs so that they can solve problems in the game. A concept, sign, and object can be interpreted endlessly (reference). 
Each interpretation can add new knowledge. Signs can be verbal, visual, gestural, musical (reference). A sign is a representation of an object. Interpretation is a thought or notation to represent an object. Sign only acts as a sign if a subject considers it a sign, interpreters exist if and only if there is a sign (reference). Interpretation or sign users is the concept of thinking of people using signs and lowering it to a certain meaning or meaning that is in someone's mind about the object referred to by a sign (Kralemann, et. all, 2013; Yang \& Hsu, 2015).

Research related to playing mathematics and semiotics has been carried out by many previous researchers, including (Nakawa, 2020) the results of their research show that guided play is effective during the planned activities according to the child's socio-cultural background and readiness. From a curriculum development point of view, first, matching activities can be carried out when the child is accustomed to flexible form manipulation in the classroom. Second, manipulating various forms implicitly will improve children's skills and abilities related to suitability and equality. The results of the study (Watanabe, 2019) show that the improvement of children's abilities in cognitive and non-cognitive skills of early childhood towards math abilities is done by playing games.

The results of the study (Suryaningrum et al., 2020) relate to semiotics, the results showed that three subjects identified objects by observing objects around them. In the signmaking stage, they made the same sign, namely a rectangular image. However, in the last three stages, namely interpreting the sign, discovering the nature of the sign, and discovering the rectangular nature, they make a different way. Quitter finds two characteristics of a rectangular object and then considers them to be rectangular. Champer discovered the four characteristics of the object and then derived it into two rectangular properties. However, Climber discovered six characteristics of the sign and made all of these four rectangular properties. In addition, Climber can determine the properties of rectangles correctly. The results research of the(Ubah \& Bansilal, 2019) state that many novice teachers have difficulty identifying similar relationships between triangles that appear in various variations of geometric object configurations. While some participants could easily make use of the two registers to express relationships, one student who initially made a lot of mistakes was only able to distinguish the relationships that were necessary with the help of concrete representations that could be physically manipulated. Therefore this study provides an example of how a student's mistakes can be used as a learning resource to lead to meaningful learning.

From some of the studies above, no one has examined playing semiotic-based early childhood mathematics. Semiotic-based math play is an activity to play using signs or symbols. Semiotics are signs or symbols that can stimulate the child's ability to interpret the signs so that they can solve problems in the game. This study aims to describe semiotic based early childhood mathematics play activities. This research is important to do to contribute to education, especially education for early childhood related to semiotic-based play activities that can stimulate children to develop six aspects of child development, namely religious and moral values, social emotional, cognitive, language, art and physical motor skills.

\section{METHOD}

Playing mathematics based on semiotics is an activity of playing using mathematical symbols using semiotics in the form of images, mathematical symbols. Early childhood activities when playing semiotic-based mathematics were recorded using videos, observed and recorded using field notes. According to (Creswell, 2012), the procedure for this research is descriptive exploratory.

The research was conducted at the PAUD Lab School, Muhammadiyah University of Jember. The research subjects were 5 children from group B. With the criteria (1) children can count 1 to 10, (2) children can understand symbols, (3) children can understand instructions for semiotic-based math play activities, (4) children can participate in playing activities with enthusiasm 
This study describes the semiotic-based early childhood math activities. Indicators of semiotic-based early childhood mathematics play are presented in Table 1.

Table 1 Indicators of Early Childhood Mathematics Playback Based on Semiotics

\begin{tabular}{llll}
\hline $\begin{array}{c}\text { Mathematical play } \\
\text { components based } \\
\text { on semiotics }\end{array}$ & \multicolumn{1}{c}{ Indicator } & \multicolumn{1}{c}{ Activities of students } \\
\hline Gather information & $\begin{array}{l}\text { Gather information } \\
\text { about semiotic based } \\
\text { math games }\end{array}$ & 1. & $\begin{array}{l}\text { Students collect information related to } \\
\text { semiotic-based math game rules }\end{array}$ \\
Identifying objects & $\begin{array}{l}\text { Selecting relevant } \\
\text { objects }\end{array}$ & $\begin{array}{l}\text { 1. } \\
\text { 2. }\end{array}$ & $\begin{array}{l}\text { Students look for objects that match the game } \\
\text { Ltudents count the number of objects found }\end{array}$ \\
Look for a sign & $\begin{array}{l}\text { Look for relevant } \\
\text { signs }\end{array}$ & $\begin{array}{l}\text { 1. } \\
\text { 2. }\end{array}$ & $\begin{array}{l}\text { Students look for relevant marks } \\
\text { number of objects found at the object }\end{array}$ \\
Interpreting the sign & $\begin{array}{l}\text { Associating the sign } \\
\text { with the knowledge } \\
\text { that has been } \\
\text { previously owned } \\
\text { Retelling play } \\
\text { activities }\end{array}$ & $\begin{array}{l}\text { 1. } \\
\text { 2tudents associate the sign with prior } \\
\text { knowledge }\end{array}$ \\
Recalling & $\begin{array}{l}\text { Students look for all the signs according to the } \\
\text { objects found }\end{array}$ \\
\hline
\end{tabular}

The stages of playing semiotic-based early childhood mathematics are (1) Prepare learning media in the form of objects that taste sweet (candy and sweet-tasting snacks, and objects that do not have a taste as challenges for children as well as pictures in the form of cards and numbers; (2) putting food that tastes sweet by hiding it both indoors and outdoors; (3) invite children to form a circle, say hello and say hello, and pray to start activities; (4) asking the child's feelings; (5) deliver playing material; (6) delivering the play steps; (7) provide opportunities for children to ask questions about things that children do not understand before the game starts. The child plays the game: (a) looking for the cute one, if you find the child counts the number of the sweetie and matches the picture card that matches the number of the sweet one found, in finishing the child will take the number (symbol) that corresponds to the number of the sweetie and the number of pictures on the card. The child can take the same symbol (number) as many as can be found in the prepared number box, (b) the game is over when each child has found a simanis, and brings it to the teacher with a picture card and a number symbol; (8) recalling about children's experiences.

To support the implementation of research, researchers need supporting instruments, namely tools used to collect semiotic reasoning data to find the formula for the area of a flat shape, the supporting instruments needed include: (1) audio-visual recording device, used to record the activities of relatives in semiotic-based mathematics playing activities. The results of the recordings will be replayed after the research, which aims to allow researchers to see carefully the students' activities while playing semiotic-based mathematics; (2) the observation sheet used to observe students while playing semiotic-based mathematics. The observation sheet used contains a description of semiotic-based math play activities. To fill in the observation sheet, the observer only needs to tick the column provided; (3) field note sheets are used to record things that occur in the field that are not included in the observation sheet. Field notes sheet in the form of notes on semiotic-based math activities that have not been recorded on the observation sheet. Prior to use, the observation sheet and the width of the field notes were validated by experts. 
The collected data were analyzed using qualitative analysis techniques. One of the data analysis techniques used is the constant comparative method. The fixed comparison method is called because the data analysis in this study will constantly compare one unit to another, and then constantly compare categories with other categories. Analisis data dilakukan melalui 3 tahap yaitu: 1) selecting data that are in accordance with the research focus, 2) presenting data by grouping data based on perice semiotic theory which consists of three elements, namely objects, signs, and interpretants (Godzich, 1981) (Eco, 1981) analyzing mathematical play activities in early childhood based on semiotics, 4) draw conclusions based on data from research findings. The design of this research activity can be seen in Picture 1.

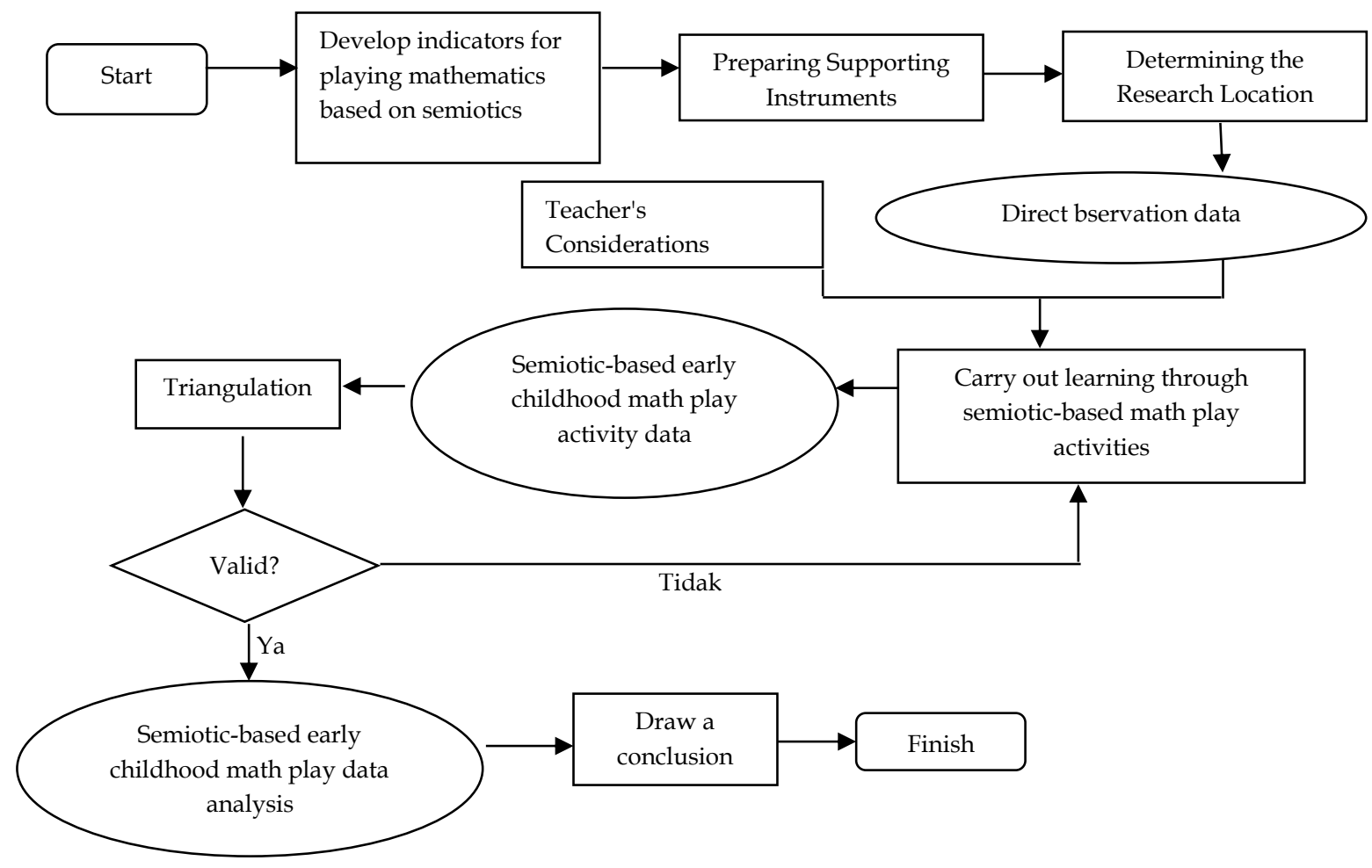

Picture 1. Research Activity Design Flowchart

\section{RESULT AND DISCUSSION}

The initial activity carried out by the research subject was gathering information. The indicator that appears is to collect information about semiotic-based math games. At this stage, the activities carried out by the research subjects were collecting information related to the rules of semiotic-based mathematics games. This is in accordance with the opinion of (Lodewyk \& Bracco, 2018) which states that in the early stages of the game, students are encouraged to reflect on aspects of the game including game rules, skills and game strategies. The teacher explains the steps of playing semiotic-based mathematics. In this play activity, the subject must look for the sweet one, namely the object that tastes sweet. After finding the sweetie, the subject must look for a card with a picture, then match the number of sweetie. The next stage, the subject takes a sign (number) that corresponds to the number of the sweetie. After finding the sign (number), the subject must take as many symbols (numbers) as can be found in the prepared number box. The five research subjects listened to the teacher's explanation of the steps of a semiotic-based math game. At this initial stage, it was found that all subjects understood the teacher's explanation.

The second stage in semiotic-based math games is to identify objects. The indicator that appears is to select the relevant object. At this stage, the first activity carried out by the subject is looking for objects that are suitable for the game, namely the sweet. Simanis is a concrete 
object that tastes sweet. The five subjects were very enthusiastic about finding the sweet one. This is in accordance with the opinion (Smith \& Chao, 2018; Wiwik Pratiwi, 2017) which states that every early childhood child really likes playing. The five subjects were looking for the sweetheart on the school yard, and on the school game. In the activity of looking for the sweetie, two subjects, namely subject 1 (S1) and subject 2 (S2) took the ball which is considered the sweetie. The two subjects showed the ball to the teacher. To find out the reason for the subject to take the ball as sweetie, the teacher conducted an interview with subject 1 (S1). The sweetness found by students but not in accordance with the teacher's instructions can be seen in Table 2

Table 2. The Sweetness Found By The Subject, But Not According to The Teacher's Instructions

\begin{tabular}{cl}
\hline Subject to- & The sweet found not suitable \\
\hline 1 & Pink ball \\
2 & Red ball \\
3 & Can't find the sweet one \\
5 & Can't find the sweet one \\
\hline
\end{tabular}

There is one subject, namely subject 3 (S3) who managed to find the sweetie under the seesaw. After finding the sweetie, S3 reported it to the teacher. To continue playing activities, the teacher asks S3 to calculate the simanis that has been found. According to the teacher's instructions, S3 calculates the ones that are found. S3 finds 2 things that taste sweet.

From the teacher's observations, four subjects had difficulty finding their sweetie. Seeing this, the teacher asked the subjects to gather to get an explanation from the teacher. This activity is in accordance with the results of (Grünke, 2020) which states that in solving game problems, at a certain stage the teacher provides assistance to students when experiencing difficulties. After the five subjects gathered, the teacher explained that what they were looking for was sweet, namely things that tasted sweet. The location of your sweetie starts from the school gate to the playground. Your sweetie can be under toys, in tree boxes in the gazebo, in the hand washing area and other places where your sweetie can hide.

After receiving intervention from the teacher, the four research subjects immediately ran on the schoolyard to find the sweetie and count the number of sweeties found. S1 finds 1 sweet tasting item in the gazebo, S2 finds 10 cute ones under the tree, S4 finds 3 sweet ones in the tree, and S5 finds 9 cute ones in a prosthetic toy. The list of sweets found by research subjects is presented in Table 3.

Table 3 The Sweetness Found By Research Subjects Subjek

\begin{tabular}{|c|c|c|c|}
\hline Subject to- & Sweets found & Amount of sweet & Total \\
\hline 1 & Heart shaped candy & 1 & 1 \\
\hline \multirow[t]{3}{*}{2} & Heart shaped candy & 1 & 10 \\
\hline & Square candy & 6 & \\
\hline & Beng-beng & 4 & \\
\hline \multirow[t]{2}{*}{3} & Heart shaped candy & 1 & 2 \\
\hline & Beng-beng & 1 & \\
\hline \multirow[t]{3}{*}{4} & Heart shaped candy & 1 & 4 \\
\hline & Square candy & 2 & \\
\hline & Beng-beng & 1 & \\
\hline \multirow[t]{3}{*}{5} & Heart shaped candy & 1 & 9 \\
\hline & Square candy & 5 & \\
\hline & Beng-beng & 4 & \\
\hline
\end{tabular}

The third stage of the semiotic-based mathematics play activity is to look for signs. The indicator that appears is to look for relevant signs. This is in accordance with the opinion 
(Arzarello \& Sabena, 2011; Brier, 2018) which states that images are signs that represent trueto-life properties with their own simple nature. Where simple means that these properties are relevant to the original nature. At this stage, the activities carried out by the research subject are looking for signs and selecting signs that are relevant to the number of objects found at the object identification stage. This is in accordance with the opinion (Kralemann, et al., 2013; Schreiber, 2013; Suryaningrum \& Ningtyas, 2019) the results of observing signs from external students, according to the objects found.

At this stage, the five research subjects looked for signs that were placed in five different places. S1, S3 and S4 look for a sign on the spin play, while S2 and S5 look for a sign on the swing. After finding the sign, the five research subjects chose a sign that was relevant to the number of objects found at the object identification stage. S1 chooses a picture card with one sign (picture of fruit) which has a number symbol 1.S2 chooses a picture card with ten signs (a picture of fruit) that has a symbol of 10. S3 chooses a picture card with three signs (picture of fruit) which has a symbol of number $2 \mathrm{~S} 4$ selects a picture card with three marks (a picture of a fruit) that has the number 3 symbol. S5 selects a picture card with nine marks (a picture of a fruit) that has the symbol 9.

The fourth stage of the semiotic-based mathematical play activity is interpreting signs. The indicator that appears is associating the sign with the knowledge that has been previously owned. This is in accordance with the opinion (Brier, 2015; Yakin \& Totu, 2014) which states that an object is something that represents the resulting interpretant. Interpretation is a response to an object through the interpretation of signs.

At this stage, the activities carried out by the research subjects were the five subjects associated the signs with the knowledge they previously had and looked for all signs according to the objects found. A person can have different interpretations related to images, this depends on how the person interprets the image image (Burgos \& Godino, 2020; Gravells, 2017; Kralemann, et al., 2013).The five subjects associated the number of sweeties found with a numeric symbol representing the number of sweeties. From the observations, subject 5 experienced confusion in looking for the symbol number 9. S5 had difficulty distinguishing the number 6 from the number 9 .

The fifth stage of semiotic-based mathematical play is recalling. The indicator that appears is the retelling of playing activities. This is in accordance with the opinion (Susanti, 2018) which states that remembering is an activity that students do to be able to re-express what is known about a problem. At this stage, the activity carried out by the research subject is to retell the play activities that have been carried out. S1 tells of the activities carried out when playing semiotic-based mathematics. In the early stages of S1 looking for the sweetheart on the school yard. S1 saw the ball in the school yard, it turned out that the ball was not sweet, because it did not taste sweet. S1 looks for the sweetie again, begged, begged for games, and finally S1 finds the sweetie in the gazebo. After finding the sweetie, S1 looks for a picture card that contains a picture of the fruit and a number sign / symbol that states the number of sweeties found. S1 chooses a picture card with one sign (picture of fruit) that has the number 1 symbol. After finding the picture card, S1 collects all the number 1 signs / symbols provided in the box.

At the recalling stage, S2 said that initially S2 thought the ball was sweet, it turned out that the ball was not sweet because the sweet was something that tasted sweet. S2 looks for the sweetie and finds the sweetie under the tree. After finding the sweetie, S2 looks for a picture card that contains a picture of fruit and a number sign / symbol that states the number of sweeties found. S2 chooses a picture card with one sign (picture of fruit) that has the number 10 symbol. After finding the picture card, S2 collects all 10 signs / symbols provided in the box. S2 asked the teacher if sweetie could be brought home. The teacher said they could take it home. S2 says Alhamdulillah as a thanksgiving to Allah. 
In contrast to S2, in the activity of playing semiotic-based mathematics, S3 sees S1 and S2 take the ball, S3 does not take the ball because S3 considers the ball not something that tastes sweet. S3 finds the sweetie under the seesaw. After finding the sweetie, S3 looks for a picture card that contains a picture of fruit and a number sign / symbol that states the number of sweeties found. S3 chooses a picture card with one sign (fruit image) that has the number 2 symbol. After finding the picture card, S3 collects all the number 2 signs / symbols provided in the box.

S4 tells that in a semiotic-based math play activity, S4 was initially confused in looking for the sweetie. After receiving intervention / explanation from the teacher regarding what is sweet, the place where the sweet is hiding. S4 tries to find the sweetie in the toy place, on the tree, in the grass. S4 finds the sweetie in the tree. After finding the sweetie, S4 looks for a picture card that contains a picture of fruit and a number sign / symbol indicating the number of sweeties found. S4 chooses a picture card with one sign (fruit picture) that has the number 3 symbol. After finding the picture card, S4 collects all the number 3 signs / symbols provided in the box.

In the final stage of playing semiotic-based mathematics, S5 stated that this game is very fun, many challenges, requires understanding to be able to find the sweet one. S5 finds the sweetie under a prosthetic toy. After finding the sweetie, S5 looks for a picture card that contains a picture of fruit and a number sign / symbol that indicates the number of sweeties found. S5 selects a picture card with one sign (fruit picture) that has the number 9 symbol. After finding the picture card, S4 collects all the 9 number marks or symbols provided in the box.

The results of observations on semiotic-based mathematics play activities, the five research subjects looked enthusiastic in participating in each stage of playing activities. S1 looks happy even though it only gets one sweetie. The same thing is seen in S2, although S2 found the sweetest last, but S2 was very happy to follow the game. S2 finds the last sweetie because while playing, S2 has a stomachache problem and has to go to the toilet first. S5 also looks enthusiastic in following the game, even though at the stage of collecting all the 9 signs/symbols provided in the box, it is confused to distinguish the number 6 and the number 9.

\section{CONCLUSION}

From the results of the study it can be said that in the activities carried out by children in playing mathematics, in the early stages of collecting information regarding the rules in playing mathematics based on semiotics. In this activity, children listen to the teacher's explanation regarding the rules of playing mathematics based on semiotics. After knowing the rules of the game, the child looks for objects, namely objects that taste sweet. After finding the object, the child counts the number of objects that have been found. The next activity that children do is look for signs that match the number of objects. At this stage, the child connects with the knowledge that has been previously owned, namely the ability to number and count. The last activity in playing semiotic-based mathematics is recall. At this stage, the child retells the activities that have been carried out. The results of this study have not revealed the development of children who are stimulated when children play semiotic-based mathematics. Therefore, for further researchers to examine the developmental aspects of being stimulated in math play activities in children based on semiotics.

\section{ACKNOWLEDGEMENT}

The researchers' gratitude goes to the Research Institute and Community Service (LPPM) Universitas Muhammadiyah Jember version which provides research funding so that the research implementation runs smoothly. The researchers also express their gratitude to the Principal of the Lab School PAUD Yasmin who has given the researcher the opportunity to carry out research on the students of group $B$. 


\section{REFERENCES}

Arzarello, F., \& Sabena, C. (2011). Semiotic and theoretic control in argumentation and proof activities. Educational Studies in Mathematics, 77(2-3), 189-206. https://doi.org/10.1007/s10649-010-9280-3

Brier, S. (2015). Cybersemiotics and the reasoning powers of the universe: philosophy of information in a semiotic-systemic transdisciplinary approach. Green Letters, 19(3), 280-292. https://doi.org/10.1080/14688417.2015.1070684

Brier, S. (2018). Transdisciplinarity across the Qualitative and Quantitative Science through C.S. Peirce's Semiotic Concept of Habit. Open Information Science, 2(1), 102-114. https://doi.org/10.1515/opis-2018-0008

Burgos, M., \& Godino, J. D. (2020). Semiotic Conflicts in the Learning of Proportionality: Analysis of a Teaching Experience in Primary Education. International Electronic Journal of Mathematics Education, 15(3). https:// doi.org/10.29333/iejme/7943

Creswell, J. W. (2012). Educational research: Planning, conducting, and evaluating quantitative and qualitative research. In Educational Research (Vol. 4). https://doi.org/10.1017/CBO9781107415324.004

Fauziddin, M. (2015). Peningkatan Kemampuan Matematika Anak Usia Dini Melalui jam Pintar. Jurnal Obsesi : Jurnal Pendidikan Anak Usia Dini, 1(1), 49-54.

Godzich, W. (1981). [The Theory of Signs and the Role of the Reader]: Apolog... The Bulletin of the Midwest Modern Language Association, 14(1), 53. https://doi.org/10.2307/1314869

Gravells, J. (2017). Semiotics and Verbal Texts. In Semiotics and Verbal Texts. https://doi.org/10.1057/978-1-137-58750-3

Grünke, M. (2020). "The Most Important Things in Life Are Good Friends and a Good Bullpen": An Interview with Scott Eyre about Playing Major League Baseball with ADHD and How the Sport Can Help Struggling Students to Succeed. Insights into Learning Disabilities, 17(2), 129-136.

Guirguis, R. (2018). Should we let them play? Three key benefits of play to improve early childhood programs. International Journal of Education and Practice, 6(1), 43-49. https://doi.org/10.18488/journal.61.2018.61.43.49

Kralemann, Björn and Lattmann, C. (2013). Models as icons : modeling models in the semiotic framework of Peirce ' s theory of signs. Synthese, 190(16), 3397-3420. https://doi.org/10.1007/s11229-012-0176-x

Laily, A., Jalal, F., \& Karnadi, K. (2019). Peningkatan Kemampuan Konsep Matematika Awal Anak Usia 4-5 Tahun melalui Media Papan Semat. Jurnal Obsesi : Jurnal Pendidikan Anak Usia Dini, 3(2), 396. https:// doi.org/10.31004/obsesi.v3i2.214

Lodewyk, K. R., \& Bracco, E. (2018). Differences in Adaptive Outcomes between Previous Physical Education and a Teaching Games for Understanding Games Unit in Adolescent Girls. ICHPER-SD Journal of Research, 10(1), 12-20.

Munawaroh, H. (2017). Pengembangan Model Pembelajaran dengan Permainan Tradisional Engklek Sebagai Sarana Stimulasi Perkembangan Anak Usia Dini. Jurnal Obsesi : Jurnal Pendidikan Anak Usia Dini, 1(2), 86. https://doi.org/10.31004/obsesi.v1i2.19

Nakawa, N. (2020). Proposing and modifying guided play on shapes in mathematics teaching and learning for zambian preschool children. South African Journal of Childhood Education, 10(1), 1-11. https:// doi.org/10.4102/sajce.v10i1.802

Ostler, E. (2011). Teaching adaptive and strategic reasoning through formula derivation: Beyond formal semiotics. International Journal of Mathematics Science Education, 4(2), 16-26.

Pradana, P. hadi. (2016). Pengaruh Permainan Balok Angka Terhadap Kemampuan Mengenal Lambang Bilangan Pada Anak Usia Dini. Obsesi : : Jurnal Pendidikan Anak Usia Dini, $2(2), 36-42$. 
Presmeg, N., Radford, L., Schubring, G., \& Kadunz, G. (2008). Semiotics in Mathematics Education and Culture. In Semiotic Perspectives in the Teaching and learning of Mathematics Series (Vol. 1, Issue 1/2). https:/ / doi.org/10.1007/978-3-319-31370-2

Rohmah, N. (2016). Bermain Dan Pemanfaatannya Dalam Perkembangan Anak Usia Dini. Jurnal Tarbawi, 13(2), 27-35.

Sari, C. R., Hartati, S. H., \& Yetti, E. (2019). Peningkatan Perilaku Sosial Anak melalui Permainan Tradisional Sumatera Barat. Jurnal Obsesi : Jurnal Pendidikan Anak Usia Dini, 3(2), 416. https:// doi.org/10.31004/obsesi.v3i2.225

Schreiber, C. (2013). Semiotic processes in chat-based problem-solving situations. Educational Studies in Mathematics, 82(1), 51-73. https:// doi.org/10.1007/s10649-012-9417-7

Smith, M. M., \& Chao, T. (2018). Critical science and mathematics early childhood education: Theorizing reggio, play, and critical pedagogy into an actionable cycle. Education Sciences, 8(4). https:// doi.org/10.3390/educsci8040162

Suryaningrum, C. W., \& Ningtyas, Y. D. W. K. (2019). Multiple representations in semiotic reasoning. Journal of Physics: Conference Series, 1315(1). https://doi.org/10.1088/1742-6596/1315/1/012064

Suryaningrum, Christine Wulandari, Purwanto, Subanji, Susanto, H., Ningtyas, Y. D. W. K., \& Irfan, M. (2020). Semiotic reasoning emerges in constructing properties of a rectangle: A study of adversity quotient. Journal on Mathematics Education, 11(1), 95-110. https:// doi.org/10.22342/jme.11.1.9766.95-110

Susanti, V. D. (2018). Analisis Kemampuan Kognitif dalam Pemecahan Masalah Berdasarkan Kecerdasan Logis - Matematis. Jurnal Matematika Dan Pendidikan Matematika, 3(1), 71-83. https:// doi.org/10.33578/prinsip.v1i2.26

Ubah, I., \& Bansilal, S. (2019). The use of semiotic representations in reasoning about similar triangles in Euclidean geometry. Pythagoras, 40(1), 1-10. https:// doi.org/10.4102/pythagoras.v40i1.480

Watanabe, N. (2019). Effective Simple Mathematics Play at Home in Early Childhood: Promoting both Non-cognitive and Cognitive Skills in Early Childhood. International Electronic Journal of Mathematics Education, 14(2), 401-417. https:// doi.org/10.29333/iejme/5739

Wiwik Pratiwi. (2017). Konsep Bermain Pada Anak Usia Dini. In Manajemen Pendidikan Islam (Vol. 5).

Yakin, H. S. M., \& Totu, A. (2014). The Semiotic Perspectives of Peirce and Saussure: A Brief Comparative Study. Procedia - Social and Behavioral Sciences, 155(October), 4-8. https:// doi.org/10.1016/j.sbspro.2014.10.247

Yang, C., \& Hsu, T. (2015). Applying Semiotic Theories to Graphic Design Education: An Empirical Study on Poster Design Teaching. International Education Studies, 8(12), 117. https://doi.org/10.5539/ies.v8n12p117 